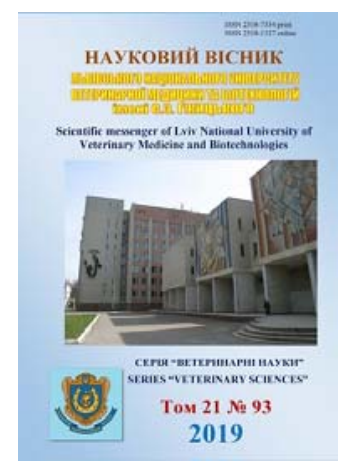

\author{
Науковий вісник Дьвівського національного університету \\ ветеринарної медицини та біотехнологій імені С.3. Гжицького. \\ Серія: Ветеринарні науки \\ Scientific Messenger of Lviv National University \\ of Veterinary Medicine and Biotechnologies. \\ Series: Veterinary sciences
}

\title{
The determination of acute toxicity parameters of "Imkar-120"
}

\author{
A.A. Fotina ${ }^{1}$, V.A. Levytska ${ }^{2}$ \\ ${ }^{1}$ Sumy National Agrarian University, Sumy, Ukraine \\ ${ }^{2}$ State Agrarian and Engineering University in Podilya, Kamianets-Podilskyi, Ukraine
}

Article info

Received 15.01.2019

Received in revised form 21.02.2019

Accepted 22.02.2019

Sumy National Agrarian University, Gerasim Kondratyev Str., 160, Sumy, 40000, Ukraine.

State Agrarian and Engineering University in Podilya, 13, Schevchenko Str., KamianetsPodilskyi, Khmelnytskyi region, 32300, Ukraine

Tel.: +38-067-381-20-12 E-mail:Levytska28@gmail.com
Fotina, A.A., \& Levytska, V.A. (2019). The determination of acute toxicity parameters of "Imkar120". Scientific Messenger of Lviv National University of Veterinary Medicine and Biotechnologies. Series: Veterinary sciences, 21(93), 10-14. doi: 10.32718/nvlvet9302

Vector-Borne Diseases are a variety of infectious and invasive diseases of animals and humans, the agents of which extend from one to another susceptible subject with the participation of hemopoiesis (ticks, insects, etc.). For the purpose of treatment of blood parasitic transmissive diseases, domestic and foreign researchers tested a significant number of drugs of different chemical composition. In connection with the insufficient on the domestic market of drugs on the basis of imidokarb dipropionate for the treatment of blood-parasitic diseases in animals, the Scientific-Production-Technical Enterprise "Brovapharma" established and conducted the state registration of the drug "Imcar-120", which blocks the synthesis of polyamine; it also has significantly less toxicity than dimeters of aceturates. It provides a broad spectrum of antiprotozoal effects on pathogens of pyroplasmiosis of the genus Babesia (Babesia bovis, B. ovis, B. bigemina, B. colchica, B. equi, B. divergens, B. canis, B. caballi, B. gibsonii i Francaiella colchica); Teilerian species (Theileria annulata, T. sergenti, T. mutans, T. orientalis, T. ovis, T. recondita, T. tarandirangiferis); Nuttallia equi and the genus of Anaplasma (Anaplasma marginale, A. ovis, Ehrlichia canis) with their mono- or mixed infestation. Pre-clinical research "Determination of toxicological properties of the drug Imcar-120" was carried out on the basis of vivarium of the Faculty of Veterinary Medicine of Sumy NAU. Study of parameters of acute toxicity of the study drug was performed on 50 clinically healthy white mice in males and females. Before the experiment, the individual weight of the body of animals selected for the experiment was 18-22 g, the age was 8-9 weeks. In the first stage, preliminary experimental studies were conducted to determine the variation of dose limits before the main stage of the studies. At the same time the drug was administered intragastrically in doses: 2500, 3500, 4500, 5500, 6500, $7500 \mathrm{mg} / \mathrm{kg}$. Each dose was given to three animals. After the introduction of the drug for monitoring animals, the experiment was carried out 14 days, the first day - every hour. For the expanded stage of the experiment, four experimental groups $(n=8)$ of animal analogues were formed, in which the study drug was injected under the same conditions as in the previous stage of the experiment at a rate of $3800,4300,4800$ and $5300 \mathrm{mg} / \mathrm{kg}$ of body weight. In the course of studies to determine the parameters of acute toxicity of the drug Imkar-120 it was determined half-lettable dose of the drug. According to R. Kerber's method, DL 50 was $4456.25 \mathrm{mg} / \mathrm{kg}$, therefore according to the classification of GOST 12.1.007-76 the preparation Imkar-120 should be classified as hazard class III by injection into the stomach - substances are moderately dangerous.

Key words: acute toxicity, Imkar-120, tick-borne diseases, ticks, babesiosis.

\section{Визначення параметрів гострої токсичності "Імкар-120"}

\author{
Г.А. Фотіна ${ }^{1}$, В.А. Левицька ${ }^{2}$ \\ ${ }^{1}$ Сумський начіональний аграрний університет, м. Суми, Украӥна \\ ${ }^{2}$ Подільський державний аграрно-технічний університет, м. Кам'янецьь-Подільський, Украӥна
}

Трансмісивні хвороби (Vector-Borne Diseases) - цее різновид інфекиійних та інвазійних хвороб тварин і людей, збудники яких поиирюються від одного до іншого сприйнятливого суб'єкту за участі кровосисних членистоногих (кліщів, комах тошо). 3 метою 
лікування кровопаразитарних трансмісивних захворювань вітчизняними і зарубіжними дослідниками випробувано значну кількість лікарських препаратів різного хімічного складу. У зв'язку з недостатністю на вітчизняному ринку препаратів на основі імідокарба дипропіонату для лікування кровопаразитарних захворювань у тварин НВФ “Бровафарма” створено та проведено державну реєстрацію препарату “Імкар-120”, який блокує синтез поліаміну; він також має істотно меншу токсичність порівняно з діміназена ацетуратом. Він забезпечує широкий спектр антипротозойного впливу щзодо збудників піроплазмідозів з роду бабезій (Ваьеліа bovis, B. ovis, B. bigemina, B. colchica, B. equi, B. divergens, B. canis, B. caballi, B. gibsonii $i$ Francaiella colchica); pody meüлepiŭ (Theileria annulata, T. sergenti, T. mutans, T. orientalis, T. ovis, T. recondita, T. tarandirangiferis); родy нуталіü (Nuttallia equi) ma pody анаплазмів (Anaplasma marginale, A. оvis, Ehrlichia canis) при їх моно- чи змішаному перебігу інвазій. Доклінічні дослідження Визначення токсикологічних властивостей нового експериментального препарату “Імкар-120” проводили на базі віварію факультету ветеринарної медицини Сумського НАУ. Вивчення параметрів гострої токсичності досліджуваного препарату проводили на 50 клінічно здорових безпородних білих мимах - самиях і самках. Перед початком досліду індивідуальна маса тіла тварин, відібраних для експерименту, становила 18-22 2, вік - 8-9 тижнів. На периому етапі з метою встановлення варіативних меж доз перед проведенням основного етапу досліджень були проведені попередні експериментальні дослідження. При цьому препарат вводився внутрішньошлунково в дозах: 2500, 3500, 4500, 5500, 6500, 7500 мг/ка. Кожну дозу задавали трьом тваринам. Після введення препарату спостереження за тваринами експерименту проводилося 14 діб, першу добу - щогодинно. Для проведення розгорнутого етапу експерименту було сформовано чотири дослідні групи (n=8) тварин-аналогів, яким досліджуваний препарат вводили при тих же умовах, щзо і на попередньому етапі експерименту з розрахунку 3800, 4300, 4800 i 5300 мг/кг маси тіла. У ході досліджень з встановлення параметрів гострої токсичності препарату “Імкар-120” визначено його напівлетальну дозу. За методом Р. Кер-

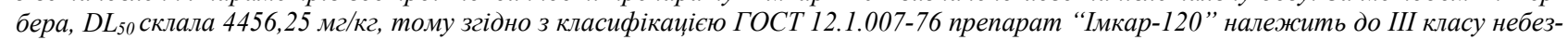
пеки при введенні в илунок-речовини помірно небезпечні.

Ключові слова: гостра токсичність, “Імкар-120”, трансмісивні хвороби, кліші, бабезіоз.

\section{Ветуп}

Українські ветеринарні фахівці відзначають неухильне зростання захворюваності собак трансмісивними захворюваннями (бабезіоз, анаплазмоз, ерліхіоз тощо). Причому змінився як сезонний характер цих захворювань, так і їх поширеність - спалахи спостерігають навіть у собак, що мешкають тільки в умовах міських квартир. Зростає і пропорція популяції інвазованих кліщів, що призводить до підвищення ймовірності зараження тварини після укусу біологічних переносників. Очевидно, що при такій тривожній динаміці захворювання собак даними протозоозами особливої актуальності набуває проблема оптимального вибору специфічного лікувального хіміопрепарату (Mokryi, \& Ksyonz, 2017; Mushynskyi \& Levytska, 2018; Dubova \& Duboviy, 2018).

3 метою лікування тварин за трансмісивних кровопаразитарних хвороб вітчизняними і зарубіжними дослідниками випробувано значну кількість лікарських препаратів різного хімічного складу (Zverev, 2008). Однак більшість цих засобів виявилося недостатньо ефективними або були високотоксичними. Специфічних хіміотерапевтичних засобів, які б забезпечували тривалу профілактичну дію, донині не знайдено. Традиційно для цієї мети найчастіше призначали препарати на основі діміназен ацетурату: азидин, береніл, бабезан, верібен, діміназін, діміна-кел тощо. Однак їх використання нерідко супроводжувалося серйозними побічними ефектами, особливо у таких порід собак як коллі, шелті, бобтейли, шарпеї, чаучау, кавказькі та середньоазіатські вівчарки, боксери, а також хаскі. У собак названих порід лікарські засоби на основі діміназен ацетурату можуть проникати через гематоенцефалічний бар'єр, що зумовить важкі ураження центральної нервової системи, а іноді - i загибель тварин.

Як повідомляє ряд дослідників, лікарські форми на основі діміназен ацетурату стерилізують організм тварини від збудника, тобто забезпечують повне зникнення паразитів з крові через 48 годин після введен- ня лікарських засобів, а при введенні за 5-17 днів до інвазування - також профілактує хворобу. Проте, за повідомленнями інших авторів, введення препаратів на основі діміназен ацетурату не завжди забезпечувало стерилізацію організму собак від збудників виду Babesia canis (Zverev, 2008; Akimov et al., 2016).

Виходячи 3 того, що основний спектр сучасних препаратів для лікування собак при бабезіозі складають лише дві групи засобів: препарати на основі імідокарбу (імізол, піро-стоп, форти-карб тощо) та на основі діміназину (верибен, неозидин, піросан тощо), інші автори провели їх тестування на двох великих групах собак $(\mathrm{n}=50)$, хворих на бабезіоз. Ними з'ясовано, що ефективність терапії обох засобів була достатньо високою, проте імідокарб вірогідно забезпечував коротший відновлюючий період хвороби та суттєво нижчі виражені нефро- і гепатотоксичні ефекти порівняно з показниками групи тварин, яким застосовували хіміотерапію діміназеном (Akimov et al., 2016).

За кордоном при кровопаразитарних хворобах тварин 3 позитивними результатами застосовують препарати на основі імідокарбу (Jacobson \& Clark, 1994). Однак відомості про використання імідокарбу для терапії собак дуже нечисленні, а даних щодо його профілактичної дії щодо вищеназваних хвороб практично немає.

У зв'язку з недостатністю на вітчизняному ринку препаратів на основі імідокарба дипропіонату для лікування кровопаразитарних захворювань у тварин НВФ "Бровафарма" створено та проведено державну реєстрацію препарату “Імкар-120", діюча основа його блокує синтез поліаміну а сам засіб має істотно меншу токсичність порівнянно 3 діміназен ацетуратом (Jacobson \& Clark, 1994; Prus, 2002).

Діючою речовиною препарату "Імкар-120” є імідокарбу дипропінат, який є похідним ікарбаниліду. Він забезпечує широкий спектр антипротозойного впливу щодо збудників піроплазмідозів з роду бабезій (Babesia bovis, B. ovis, B. bigemina, B. colchica, B. equi, $B$. divergens, $B$. canis, B. caballi, B. gibsonii i 
Francaiella colchica); роду тейлерій (Theileria annulata, T. sergenti, T. mutans, T. orientalis, T. ovis, T. recondita, T. tarandirangiferis); роду нуталій (Nuttallia equi) та роду анаплазмів (Аnaplasma marginale, A. ovis, Ehrlichia canis) при їх моно- чи змішаному перебігу інвазій.

Не було проведено спеціальних досліджень щодо потенційної імунотоксичності імідокарбу. Результати гематології та патологічних досліджень у дослідженнях $з$ повторною дозою токсичності не свідчать про будь-який вплив на імунну систему. В серії численних експериментів за допомогою методу рідинної хроматографії 3 ультрафіолетовим детектуванням М.К. Бекулов, В.Е. Абрамов визначили залишкові кількості імідокарбу дипропіонату в сироватці крові піддослідних тварин, а також з'ясували $\mathrm{DL}_{50}$ ін'єкційної форми $10 \%$ розчину імідокарбу 112,5 мг/кг (Novgorodceva, 1999; Zverev, 2008). Подібні дослідження 3 вивчення гострої токсичності ін'єкційного розчину імідокарбу були проведені А.А. Звєрєвим (2008), при цьому $\mathrm{DL}_{50}$ препарату в два рази меншої концентрації для лабораторних мишей становила $111 \mathrm{мг/ \kappa г.}$

Імідокарб за параметрами гострої токсичності згідно з ГОСТ 12.1.007-76 відноситься до помірно небезпечних речовин (3 клас небезпеки): $\mathrm{DL}_{50}$ при введенні білим щурам в шлунок складає 2500 мг/кг, при підшкірному введенні білим мишам - 139 мг/кг тварини (по ДР) (Zverev, 2008).

У субхронічному експерименті на білих мишах при щоденному підшкірному введенні імідокарбу протягом 15 днів встановлено, що дози 0,4 і 0,15 DL 50 є токсичними; 0,04 $\mathrm{LD}_{50}-3$ пороговою, а $0,015 \mathrm{DL}_{50}$ 3 невиявленою токсичністю (Zverev, 2008).

Імідокарбу дипропіонат в дозі 12 мг/кг маси тварини (3-кратна терапевтична доза для собак) не виявляв ембріотоксичної і тератогенної дії при щоденному введенні вагітним щурам в критичні періоди ембріогенезу.

Імідокарбу дипропіонат в терапевтичній дозі не виявляв імунотоксичної активності щодо гуморальної і клітинної імунної відповіді, не призводив до сенсибілізації організму тварин.

Імідокарбу дипропіонат при одноразовому i 7кратному парентеральному введенні собакам, яке у в 2,5 разу перевищувало терапевтичну дозу, добре переносились тваринами і не викликав змін в клінічному стані, гематологічних і біохімічних показниках (Zverev, 2008).

Імідокарб в разовій дозі 4 мг/кг маси тварини при експериментальному зараженні цуценят собак бабезіозом забезпечував виражений профілактичний ефект протягом 30 діб. Клінічними випробуваннями на собаках, спонтанно заражених бабезіозом, встановлено, що імідокарб при одноразовому внутрішньом'язовому введенні в дозі 4 мг/кг маси тварини (по ДР) забезпечував 93-100\% терапевтичну ефективність і не спричиняв гепатонефротоксичних ефектів (Otranto et al., 2009). Цей же автор зазначає, що при інших дослідженнях, за 90-денного визначення токсичності, імі- докарб застосовув трьом групам собак $(\mathrm{n}=8)$ в дозах 5, 20 та 80 мг/кг на добу. Експеримент проводився 3 метою вивчення токсичності імідокарбу діпропіонату, за перорального застосування препарату на печінку i кишечник. У фармакокінетичних дослідженнях, що проводилися Абдуллою, імідокарб вводили собакам внутрішньовенно в дозі 4 мг/кг маси тіла. Одна 313 собак загинула. Органами ураження внаслідок токсичності у цієї собаки були легені та нирки, а також деякі зміни відзначені в печінці та селезінці (Bespalova, 2006).

Клінічно наявний тосикоз характеризувався такими ознаками як млявість, слабкість і відсутність апетиту, окремі прояви дисфункцій з боку шлунковокишкового тракту, печінки, нирок і легень.

\section{Матеріал і методи досліджень}

Визначення токсикологічних параметрів експериментального препарату проводили згідно з “Методическими указаниями по определению токсических свойств препаратов, применяемых в ветеринарии и животноводстве" та “Доклінічними дослідженнями ветеринарних лікарських засобів” (Bespalova, 2006; Kotsiumbas et al., 2006; Gutyj et al., 2018; Todoriuk et al., 2018).

Доклінічні дослідження “Визначення токсикологічних властивостей препарату “Імкар - 120” проводили на базі віварію факультету ветеринарної медицини Сумського НАУ. Вивчення параметрів гострої токсичності досліджуваного препарату проводили на 50 клінічно здорових безпородних білих мишах - самцях і самках. Перед початком досліду індивідуальна маса тіла тварин, відібраних для експерименту, становила 18-22 г, вік - 8-9 тижнів.

На першому етапі з метою встановлення варіативних меж доз перед проведенням основного етапу досліджень були проведені попередні експериментальні дослідження. При цьому препарат вводився внутрішньошлунково в дозах: 2500, 3500, 4500, 5500, 6500, 7500 мг/кг маси тіла тварин.

Кожну дозу задавали трьом тваринам. Після введення препарату спостереження за тваринами експерименту проводилося 14 діб, першу добу - щогодинHo.

Для проведення розгорнутого етапу експерименту було сформовано чотири дослідні групи (n = 8) тварин-аналогів, яким досліджуваний препарат вводили при тих же умовах, що і на попередньому етапі експерименту з розрахунку 3800, 4300, 4800 і 5300 мг/кг маси тіла.

На основі отриманих даних методом Г. Кербера розраховували значення параметрів гострої токсичності препарату: $\mathrm{DL}_{0}$ (максимально переносима доза) i $\mathrm{DL}_{50}$ (середньосмертельна доза).

\section{Результати та їх обговорення}

При проведенні першого етапу досліду внутрішньошлункове введення препарату в дозах 2500 i 
3500 мг/кг маси тіла не спричиняло загибелі тварин протягом всього експерименту. Клінічний стан тварин не мав особливих змін після введення препарату в зазначених дозах. Під час спостереження за тваринами протягом 14 діб не було зареєстровано жодних відхилень показників фізіологічного стану тварин: тварини фізіологічно приймали корм та воду, у них були відсутні порушення координації і будь-яких видимих поведінкових реакцій.

Наступні випробовувані дози препарату (4500, 5500, 6500, 7500 мг/кг маси тіла були токсичними. Препарат у дозі 4500 мг/кг викликав загибель двох тварин протягом 4 годин після введення випробуваного засобу в організм. Одна тварина вижила, відновлення видимих фізіологічних реакцій організму спостерігалося наприкінці другої доби експерименту. Введення препарату в дозах 5500, 6500 і 7500 мг/кг призводило до 100\% загибелі всіх експериментальних тварин впродовж перших трьох годин після введення.
При цьому характерними були ознаки інтоксикації організму: короткочасове за збудження, яке змінювалося пригніченням, відмова від корму, часте дихання i серцебиття, порушення рухової активності, відсутність реакції на зовнішні механічні подразники.

Загибель тварини, які отримали препарат в дозі 6500 мг/кг, відбувалася в ході другої години після введення. Всі зазначені ознаки інтоксикації проявлялися за більш стрімкого перебігу. А у дозі 7500 мг/кг препарат викликав загибель всіх тварин експерименту протягом перших 35-45 хвилин після його введення.

На основі проведених досліджень були визначені дози препарату для проведення основного етапу досліджень. Введення білим мишам препарату в дозі 3800 мг/кг викликало загибель однієї тварини протягом 42 годин після потрапляння засобу в організм (табл. 1).

\section{Таблиця 1}

Визначення $\mathrm{DL}_{50}$ препарату “Імкар - 120” на білих мишах при внутрішньошлунковому введенні за методом Г. Кербера

\begin{tabular}{ccccc}
\hline Дози препарату, мг/кг маси тіла & 3800 & 4300 & 4800 & 5300 \\
\hline Вижило & 7 & 5 & 2 & 0 \\
Загинуло & 1 & 3 & 6 & 8 \\
$\mathrm{z}$ & 2,0 & 4,5 & 7,0 & \\
$\mathrm{~d}$ & 500 & 500 & 500 & \\
$\mathrm{zd}$ & 1000 & 2250 & 3500 & \\
\hline
\end{tabular}

Протягом перших двох діб у тварин спостерігалося незначне пригнічення та зменшення споживання корму, хоча і без повної його відмови. На третю добу спостереження за тваринами всі поведінкові реакції відновилися. При подальшому спостереженні за тваринами видимі порушення фізіологічного стану тварин були відсутні.

При надходженні експериментального препарату в дозі 4300 мг/кг відзначено загибель трьох тварин експерименту у проміжку між 25 і 32 годинами. У всіх тварин експериментальної групи помічали пригнічення апетиту з характерним порушенням рухових рефлексів. Хоча повна відмова від корму була відсутня. Тварини, які вижили, відновлювали видимі фізіологічні реакції на третю добу спостереження.

Внутрішньошлункове введення препарату в дозі 4800 мг/кг впродовж другої половини першої доби досліду приблизно призвело до загибелі шести тварин експерименту. При цьому відзначали у мишей явне пригнічення рефлексів, відсутність апетиту, у тварин порушувалася координація рухів. При подальшому спостереженні за мишами - падіж був відсутній.

Внутрішньошлункове ведення препарату в дозі 5300 мг/кг призводило до загибелі всіх тварин в досліджуваній групі. Поява ознак інтоксикації проходила в більш вираженій яскравій формі.

$\mathrm{DL}_{50}$ препарату розраховували за формулою:

$$
\mathrm{DL}_{50}=\mathrm{DL}_{100}-\frac{\sum(z d)}{n} \text {; }
$$

де $\mathrm{DL}_{100}$ - кількість речовини, яка викликала летальний ефект у 100\% стандартної групи піддослідних тварин протягом терміну спостереження;

$\mathrm{d}$ - інтервал між кожними двома суміжними дозами;

$\mathrm{z}$ - середнє арифметичне з числа загиблих тварин під впливом кожних двох суміжних доз;

$\Sigma(\mathrm{zd})$ - сума середньоарифметичних чисел;

$\mathrm{n}$ - кількість піддослідних тварин у кожній групі.

При визначенні середньосмертельної дози за методом Г. Кербера DL $_{50}$ становила 4456,25 мг/кг маси тіла.

При проведенні патологоанатомічного розтину загиблих тварин були встановлені зміни в шлунковокишковому тракті, характерні для гострого отруєння: геморагічне запалення слизової оболонки шлунка i кишечнику, переповнення брижових судин кров'ю, незначне збільшення печінки і селезінки.

\section{Висновки}

При визначенні середньосмертельної дози за методом Г. Кербера, $\mathrm{DL}_{50}$ склала 4456,25 мг/кг, тому відповідно до класифікації ГОСТ 12.1.007-76 препарат “Імкар-120" належить до III класу безпечності, при введенні в шлунок - речовини помірно небезпечHi.

Планується проведення подальших досліджень антипротозойного препарату, зокрема визначення пара- 
метрів хронічної токсичності препарату “Імкар-120” на лабораторних тваринах.

\section{References}

Akimov, D.Ju., Romanova, E.M., \& Shadyeva, L.A. (2016). Sravnitelnaja ocenka jeffektivnosti preparatov na osnove imidokarba i diminazina pri babezioze. Vestnik Uljanovskoj gos. s.-h. akademii. Uljanovsk, 3, 49-54. https://elibrary.ru/item.asp?id=26706940 (in Russian).

Bespalova, N.S. (2006). Sovremennye protivoparazitarnye sredstva v veterinarii. M. Kolos (in Russian).

Dubova, O.A., \& Duboviy, A.A. (2018). Hepathopathy and nephropathy in the dogs' babesiosis: pseudohepatorenal syndrome. Scientific Messenger of Lviv National University of Veterinary Medicine and Biotechnologies, 20(83), 102-107. doi: 10.15421/nvlvet8320

Gutyj, B., Grymak, Y., Hunchak, V., Mysak, A., Nazaruk, N., Brezvyn, O., Hariv, I., Shcherbatyy, A., Semeniv, B., Bushueva, I., Parchenko, V., \& Kaplaushenko, A. (2018). Preclinical searches of the preparation Thireomagnile. Ukrainian Journal of Ecology, 8(1), 688695. doi: 10.15421/2018_267.

Jacobson, L.S., \& Clark, I.A. (1994). The pathophysiology of canine babesiosis to an old puzzle. The Journal of the South African Veterinary Association, 65(3), 134-145.

Kotsiumbas, I.Ya., Malyk, O.H., \& Patereha, I.P. (2006). Doklinichni doslidzhennia veterynarnykh likarskykh zasobiv. ta in. Za red. I.Ya. Kotsiumbasa Lviv. Triada plius. 360 (in Ukrainian).

Mushynskyi, A.B., \& Levytska, V.A. (2018). Krovosysni chlenystonohi yak perenosnyky transmisyvnykh zakhvoriuvan tvaryn. Ahrarna nauka ta osvita Podillia. zb. nauk. prats mizhnar. nauk.-prakt. konfer. Ternopil: Krok, 2, 66-68 (in Ukrainian).

Novgorodceva, S.V. (1999). Jepizootologija, patogenez i terapija babezioza sobak. Avtoref. dis. kand. vet. nauk. Sibirskoe otdelenie RASHN. Ivanovo, 15-17 (in Russian).

Otranto, D., Dantas-Torres, F., \& Breitschwerdt, E.B. (2009). Managing canine vector-borne diseases of zoonotic concern. Trends in Parasitology, 4, 228-235. doi: 10.1016/j.pt.2009.01.003. https://www.ncbi.nlm. nih.gov/pubmed/19269898.

Prus, M.P. (2002). Deiaki aspekty patohenezu ta zakhodiv borotby z babeziozom sobak. Mat. 1-yi mizhn. n.prakt. vet. konf. z probl. dribn. tvaryn. Odesa. 107120 (in Ukrainian).

Todoriuk, V.B., Hunchak, V.M., Gutyj, B.V., Gufriy, D.F., Hariv, I.I., Khomyk, R.I. , \& Vasiv, R.O. (2018). Preclinical research of the experimental preparation "Ferosel T". Ukrainian Journal of Veterinary and Agricultural Sciences, 1(1), 3-9. doi: 10.32718/ujvas1-1.01.

Zakon Ukrainy "Pro zakhyst tvaryn vid zhorstokoho povodzhennia" № 3447-IV vid 21.02.2006 r. (zi zminamy). https://zakon.rada.gov.ua/laws/show/3447-15.

Zverev, A.A. (2008). Farmako-toksikologicheskaja harakteristika i terapevticheskaja jeffektivnost imidokarba 5\% pri babezioze sobak: avtoref. dis. kand. biol. nauk. M., 35 (in Russian).

Mokryi, Yu.O., \& Ksyonz, I.M. (2017). Epizootology monitoring of babezial invasion among dogs in Poltava. Scientific Messenger LNUVMBT named after S.Z. Gzhytskyj, 19(73), 149-153. doi: 10.15421/nvlvet7331. 